J02602

\title{
動的変形マイクロフィルタによるヒト全血中微量癌細胞の特異的捕捉
}

\section{Specific capturing of a small amount of cancer cells in human whole blood by dynamic deformable microfilter}

○正 熊本 清太郎 ${ }^{* 1,2}$, 福山 創一朗 ${ }^{* 1}$, 長野 誠也 ${ }^{* 1}$, 安田 敬一郎 ${ }^{* 2}$, 北村 祐介 ${ }^{* 3}$, 岩槻 政晃 ${ }^{* 4}$, 馬場 秀夫 ${ }^{* 4}$, 井原 敏博*3, 中西 義孝 ${ }^{* 3,}{ }^{* 5}$, 中島 雄太 ${ }^{* 3},{ }^{* 5},{ }^{* 6}$

Seitaro KUMAMOTO ${ }^{* 1,2}$, Souitiro FUKUYAMA*1, Seiya NAGANO*1, Keiichiro YASUDA $^{* 2}$, Yusuke KITAMURA ${ }^{* 3}$, Masaaki IWATSUKI ${ }^{* 4}$, Hideo BABA $^{* 4}$ Toshihiro IHARA ${ }^{* 3}$, Yoshitaka NAKANISHI ${ }^{* 3,{ }^{* 5}}$ and Yuta NAKASHIMA ${ }^{* 3, * 5, * 6}$

${ }^{* 1}$ 熊本大学大学院自然科学教育部 Graduate School of Science and Technology, Kumamoto University

*2 株式会社オジックテクノロジーズ Ogic Technologies Co. Ltd.

*3 熊本大学大学院先端科学研究部 Faculty of Advanced Science and Technology, Kumamoto University

${ }^{* 4}$ 熊本大学大学院生命科学研究部 Faculty of Life Science, Kumamoto University

*5 熊本大学産業ナノマテリアル研究所 Institute of Industrial Nanomaterials, Kumamoto University

*6 熊本大学国際先端科学技術研究機構 International Research Organization for Advanced Science \&

Technology, Kumamoto University

Key Words : Microfilter, Nucleic acid aptamer, Target cells, Cancer cells, Capturing

\section{1. 緒言}

癌を発症した患者の血液中には循環腫瘍細胞 (CTCs, Circulating Tumor Cells) が存在することが知られており, CTCs の個数は癌の病態に対して強い相関を示すことが確認されている(1). CTCs 検出することで，癌の早期発 見や治療の有効性などを診断できると考えられるが，数億個の血球細胞を含む血液 $1 \mathrm{ml}$ 中に CTCs はわずか数個 しか存在せず, CTCs を検出するのは非常に困難である. 本研究では, 流体力により 3 次元的かつ動的に変形可 能なマイクロフィルタを用いてヒト全血中に含まれる癌細胞を効果的に捕捉することを目的とする.

\section{2. 癌細胞捕捉実験}

マイクロフィルタはフォトリソグラフィと電鋳技術を用いて製作された複数の円弧状スリットを持つ円形の金 基板であり，マイクロフィルタの表面には癌細胞と特異的に結合する核酸アプタマーを修飾した. 3 種類のフィ ルタを用いた捕捉評価には, 癌細胞として MDA-MB-453（ヒト乳癌由来細胞）, 正常細胞として HEK293T（ヒト 胎児腎細胞由来細胞）を用いた。細胞はそれぞれ $5.0 \times 10^{5} \mathrm{cell} / \mathrm{s} / \mathrm{ml}$ の濃度に調製し， $3 \mathrm{ml} / \mathrm{h}$ の流量で $1 \mathrm{ml}$ をフィル タに送液後, 捕捉した細胞数をカウントした. その結果, 小さな円弧状のスリットを複数配置したフィルタが他 のフィルタの 6 倍以上の癌細胞を捕捉し, 最も多くの癌細胞を捕捉できることを実証した. 有限要素法によるひ ずみ解析を行った結果, 全面にわたって均等に変形する構造が癌細胞の効果的捕捉に適することを明らかにした. また，ヒトの全血を用いた評価では， $50 \mathrm{cell} \mathrm{s} / \mathrm{ml}$ の濃度で癌細胞を混入した．その結果，癌細胞の捕捉数は 21 個 であり, 約 $50 \%$ の捕捉率であるが実際の癌患者の CTCs 数と同程度の濃度でも癌細胞を特異的に捕捉できること を実証した。

\section{3. 結 言}

核酸アプタマーを修飾した動的変形可能な 3 種類のマイクロフィルタを製作し評価した結果, 効果的に癌細胞 を捕捉できるマイクロフィルタを決定した．血液中の癌細胞捕捉量を評価した結果，多量の血球細胞のなかに癌 細胞が極わずかしか存在しない場合でも特異的に捕捉することを実証した．今後は実際の患者の血中癌細胞捕捉 実験を行い，癌検查として使用寸るための検証を行う.

\section{文献}

(1) Patrizia Paterlini-Brechot et. al., Circulating tumor cells (CTC) detection: Clinical impact and future directions, ScienceDirect, Cancer Letters 253 (2007), pp. 180-204. 